Vol. 1 No. 2 September 2021, e-ISSN : 2797-8842 | p-ISSN : 2797-9431

\title{
MENINGKATKAN MOTIVASI BELAJAR PESERTA DIDIK KELAS VII B SMP NEGERI 2 TARAKAN DALAM PEMBELAJARAN ILMU PENGETAHUAN SOSIAL MELALUI PENERAPAN LESSON STUDY
}

\author{
SITY NURBAYA \\ SMP Negeri 2 Tarakan, Kalimantan Utara \\ Email: Sity nurbaya.Smpn2trk@gmail.com
}

\begin{abstract}
ABSTRAK
Dalam rangka meningkatkan motivasi dan hasil belajar IPS ,peserta didik perlu adanya peningkatan kualitas pembelajaran yang di laksanakan oleh guru melalui kegiatan pembelajaran berbasis lesson study. .Pembelajaran itu berdasarkan hasil observasi dengan pembelajaran kolaboratif melalui kegiatan lesson study dengan maksud dan tujuan ingin berbagi pengalaman dengan para guru tertutama guru IPS, penelitian ini di laksanakan dengan tujuan untuk melihat peningakatan motivasi peserta didik kelas VII B SMP Negeri 2 Tarakan dalam pembelajaran Ilmu Pengetahuan Sosial melalui penerapan Lesson Study. Penelitian ini termasuk jenis penelitian Tindakan kolaboratif. Penelitian ini di laksanakan pada tahun ajaran 2019 / 2020 pada pembelajaran IPS dengan materi atau tema Keadaan Penduduk Indonesia .Kelas yang dijadikan sebagai penelitian adalah kelas VII B yang diamati oleh 3-5 obeserver .Pelaksanaan Lesson Study di SMPN2 Tarakan dengan empat tahapan. Penerapan pembelajaran lesson study yang bertujuan untuk meningkatkan motivasi peserta didik di lakukan melalui 3 tahapan .instrumen penelitian yang digunakan berupa lembar observer plan,catatan lapangan dan refleksi lesson study dan lembar catatan perkembagan motivasi .Analisis data menggunakan pendekatan deskriptif kualitatif ,yang menggambarkan temuan- temuan selama pelaksaan penelitian. Hasil penelitian menyatakan keterlaksanan penerapan pembelajaran berbasis lesson study oleh guru model di SMPN2 Tarakan mengalami peningkatan dibandingkan dengan motifasi belajar sebelum penerapan berbasis lesson study
\end{abstract}

Kata kunci : motifasi belajar , peserta didik, , ilmu pengetahuan social lesson study

\section{PENDAHULUAN}

Kurikulum 2013 menuntut setiap guru agar dapat mengembangkan daya kreatif peserta didik untuk menjamin terlaksananya pembelajaran yang aktif, kreatif, efektif dan menyenangkan bagi peserta didik dengan proses pembelajaran saintifik yang meliputi, mengamati, menanya , mengumpulkan informasi ,mengasosiasi dan mengkomunikasikan. Untuk meningkatkan hasil belajar yang baik tentu di perlukan motivasi . motivasi belajar pada peserta didik hendaklah di anggap sebagai sesuatu yang terkait dengan kebutuhan berprestasi , kebutuhan social, memperoleh rangsangan, kebiasaan dan perasaan ingin tau yang berasal dari dalam diri peserta didik

Motifasi belajar dapat dikatakan sebagai energi dalam diri seseorang yang mendorong dan menimbulkan gerak untuk melakukan aktifitas belajar. Dari pengertian itu motivasi merupakan factor yang sangat menentukan secara langsung belajar seseorang yang akan membawa dampak terhadap hasil belajar peserta didik. Dengan kata lain semakin tinggi motivasi belajar peserta didik maka akan semakin besar pula aktifitas yang akan dilakukan peserta didik untuk mencapai tujuan belajar . Didalam Lampiran Peraturan Menteri Pendidikan Nasional nomor 19 Tahun 2007 Tanggal 23 Mei 2007 tentang standar Pengelolaan Oleh Satuan Pendidikan Dasar dan Menengah di jelaskan bahwa setiap guru bertanggung jawab terhadap mutu perencanaan kegiatan pembelajaran yang diampunya agar peserta didik mampu (1) meningkatkan rasa ingin tau nya , (2) mencapai keberhasilan belajarnya secara konsisten sesuai dengan tujuan Pendidikan, (3) memahami perekambagan ilmu pengetahuan dengan kemampuan mencari sumber informasinya , (4) mengolah informasi menjadi pengetahuan , (5) menggunakan pengetahuan untuk menyelesiakan masalah , (6) mengkomunikasikan 
pengetahuan pada pihak lain, dan (7) mengembangkan belajar mandiri dan kelompok dengan proporsi yang wajar.

Setiap pembelajaran memiliki tantangan dalam proses pembelajaran ,termasuk pembelajaran Ilmu Pengetahuan Sosial (IPS) Soemantri (2001: 92) menegaskan bahwa program pendidkan IPS merupakan perpaduan cabang - cabang Ilmu -ilmu social dan humaniora termasuk didalamnya agama, filsafat, dan Pendidikan . Bahkan IPS juga dapat mengambil aspek - aspek tertentu dari ilmu -ilmu kealaman dan tehnologi .Pembelajaran pada dasarnya untuk merubah kondisi dari tidak bisa menjadi bisa atau dari tidak tau menjadi tau atau menjadi lebih tau dari kondisi sebelumnya. Msalah utama yang umum dialami guru didalam kelas pada saat menyampaikan materi pembelajaran adalah adanya kejenuhan peserta didik didalam belajar, peserta didik tidak optimis atau tidak semangat dalam mengikuti proses pembelajaran.

Salah satu cara untuk menginspirasi kreatifitas dan inovatif pembelajaran adalah dengan melakukan pengamatan pada sebuah pembelajaran yang di lakukan oleh orang (guru) lain dan akan meningkatkan motivasi dan hasil belajar. Salah satu hasil sebuah solusi yang dilakukan yaitu pembelajaran open class yang dilakukan oleh GURU MODEL dari SMP Negeri 2 Tarakan. Oleh karena uniknya pembelajarn itu berdasarkan hasil observasi dengan pembelajaran kolaboratif melalui kegiatan Lesson Study dengan maksud dan tujuan ingin berbagi pengalaman dengan para guru terutama guru - guru IPS. Hal ini sependapat dengan Sardiman (2011 : 95) yang menyatakan bahwa metode - metode inovatif yang di perlukan untuk memotifasi peserta didik belajar yang nantinya akan berpengaruh terhadap hasil belajar para peserta didik.

Sebagai upaya dalam rangka meningkatkan motivasi dan hasil belajar IPS peserta didik perlu adanya peningkatan kwalitas pembelajaran yang dilaksanakan oleh guru melalui kegiatan Lesson study. Syamsuri dan Ibrohim (2008 : 19) menyatakan bahwa Lesson Study merupakan salah satu cara untuk meningkatkan pembelajaran yaitu melakukan kolaborasi dengan guru lain untuk merancang, mangamati dan melakukan refleksi terhadap pemeblajaran. Pada pelaksanaan nya ,kelompok guru merancang pembelajaran Bersama- sama dan Ketika diterapkan, salah satu guru bertugas melaksanakan pembelajaran sedangkan yang lain menjadi obserfer atau mengamati belajar peserta didik . Pelaksanaan refleksi telah di rancang dan dilakukan kemudian melakukan revisi sehingga di dapatkan kualitas pembelajaran yang lebih baik dari sebelumnya.

Berdasarkan latar belakang tersebud maka penelitian ini dilaksanakan dengan tujuan untuk meikhat peningkatan motifasi pererta didik kelas VII B SMP Negeri 2 Tarakan dalam pembelajaran Ilmu Pengetahuan Sosial melalui penerapan Lesson Study

\section{METODE PENELITIAN}

Penelitian ini termasuk jenis penelitian Tindakan kolaboratif yang bertujuan untuk mengungkapkan pelaksanaan kegiatan Lesson Study ,mengkaji kegiatan pelaksanaan dan mengkaji peningkatan motifasi peserta didik berbasis Lesson Study tahun ajaran 2019/2020 dalam pembelajaran IPS dengan materi atau tema Keadaan Penduduk Indonesia . Kelas yang dijadikan sebagai penelitian adalah kelas VII B yang diamati oleh 3 - 5 obserfer .Pelaksanaan Lessson Study di lakukan di SMP Negeri 2 Tarakan dengan 4 tahapan . Penelitian ini meliputi ketiga tahapan dalam LS yaitu : (1) Plan, (2)Do,(3) See. Analisis data menggunakan pendekatan Deskriptif kwalitatif yang menggambarkan temuan - temuan selama pelaksanan penelitian , mendiskipsikan motivasi peserta didik.

\section{HASIL DAN PEMBAHASAN}

A. Keterlaksanaan Lesson Study

1. SIKLUS I

1) Perencanaan pada siklus ini di lakukan beberapa hasil yaitu : 
a) Disepakati bahwa tema yang akan di ambil oleh guru model, dan sebagai pilihan kami adalah tema " Keadaan Penduduk Indonesia ' yang di awali dengan sub tema Jumlah dan pertumbuhan Penduduk Indonesia, yaitu tema yang sesuai dengan jadwal pembelajaran

b) Membuat RPP ( Rencana Pelaksanaan Pembelajaran ) sesuai dengan teori - teori yang ada

c) Fokus pengamatan aktifitas peserta didik dalam pembelajaran

2) Pelaksanaan DO yaitu :

a) Melakukan pembelajaran dengan model Discovery Learning

b) Melakukan observasi atau pengamatan terhadap sikap peserta didik pada saat pembelajaran

c) Terdapat bebrapa peserta didik yang tidak focus atau kurang kosentrasi pada saat pembelajaran

3) Pelaksanaan SEE, ditemukan permasalahan sebagai berikut :

a) Pembagian kelompok seharusnya dilakukan pada saat pembelajaran berlangsung

b) Pembagian kelompok yang tidak merata

c) Guru tidak memberikan kesimpulan pada saat pembelajaran selesai

d) Beberapa peserta didik masih kurang aktif secara mental dalam kegiatan pembelajaran

\section{SIKLUS II}

1) Perencanaan pada siklus dilakukan beberapa hasil yaitu:

a) Desain RPP sudah lebih baik dan perencanaan pengaturan juga sudah di sesuaikan dengan kondisi kelas dan peserta didik yang kurang focus

b) Media yang digunakan pada saat pembelajaran telah mencakup pemahaman materi

2) Pelaksanaan DO, yaitu :

a) Pelaksanaan pembelajaran menjadi lebih baik, peserta didik lebih berkosentrasi dan termotivasi karena guru model lebih memotivasi peserta didik dalam proses pembelajaran berupa tugas pribadi yang bersifat bermain dan menyenangkan peserta didik

b) Pada saat presentasi peserta didik lebih berani mengemukakan pendapatnya

c) Proses pembelajaran terlihat lebih hidup dan menyenangkan

3) Pelaksanaan SEE., ditemukan permasalahan sebagai berikut :

a) Proses pembelajaran berlangsung dengan baik, peserta didik memperhatikan dengan baik dan guru model menggunakan metode yang dapat memancing kosentrasi peserta didik

b) Kosentrasi peserta didik dan kelompok dari setiap kelompok lebih di fokuskan lagi

Temuan Pelaksanaan Lesson Study

Gury IPS sering kali hanya menggunakan metode ceramah sehingga pembelajaran IPS hanya di anggap sebagai pelajaran yang sangat membosankan dan hanya berisi konsep - konsep kering yang harus di hapalkan. Hal ini sejalan dengan pendapat dari kaum Gestalis yang menyesalkan penggunaaan metode menghapal di sekolah dan mereka menghendaki agar peserta didik belajar dengan pengertian , bukan hapalan academika . untuk mengatasi masalah - masalah yang di hadapi oleh guru dan murid dalam proses belajar mengajar maka perlu ditingkatkan lagi motivasi pada peserta didik untuk belajara dan motivasi pada guru untuk meningkatkan profesinya melalui kegiatan Lesson Study

\section{SIKLUS I}

Setelah siklus 1 dilaksanakan teryata ada beberapa peserta didik yang masih belum focus dalam proses pembelajaran. Hal ini karena pengelompokan peserta didik yang tidak 
seimbang, dalam arti ada beberapa kelompok yang anggotanya mampu atau terampil dalam mengungkapkan pendapat dan bahkan sebaliknya ada bebrapa kelompok yang tidak mampu . Sehingga masih di temui peserta didik yang kurang focus . Karena setiap peserta didik mempunyai keterampilan mengemukakan pendapat dalam hasil kerja , selain itu juga guru memperbaiki media dan sumber belajar peserta didik. Namun dalam siklus I ini masih ada beberapa kelemahan yaitu handout dibangikan kepada peserta didik agar peserta didik lebih dapat memahami materi pembelajaran dengan lebih baik lagi . Disamping itu juga guru memotivasi kembali peserta didik dari pembelajaran- pembelajaran sebelumnya sehingga diharapkan peserta didik lebih termotivasi lagi dalam pembelajaran serta lebih percaya diri dalam mengemukakan pendapat serta lebih antusias lagi didalam pembelajaran IPS .sehingga peserta didik yang masih kurang aktif diharapak pada pembelajaran yang akan datang lebih aktif lagi.

\section{SIKLUS II}

Dengan mengetahui beberapa kelemahan yang terjadi pada siklus I, maka pada pelaksaan siklus ke II mengalami perbaikan . setelah guru membentuk ulang masing - masing anggota kelompok dengan cara mengundi peserta didik ,dan guru memperbaiki anggota kelompok supaya lebih seimbang. Peserta didik mulai lebih focus pada proses pembelajaran dan mulai bisa lebih bekerja sama dengan kelompoknya. Disamping itu peserta didik sudah mulai berani bertanya kepada gurunya jika menemui kesulitan,demikian juga berani berpendapat dalam kelompoknya . Disamping itu peserta didik di beri kesempatan untuk lebih menampilkan dirinya dalam kegiatan tugas dengan menunjukkan daerah asal mereka kedaearah perantauan yaitu Tarakan. Guru menggunakan metode- metode yang dapat memancing kosentrasi peserta didik

\begin{tabular}{|l|l|l|l|}
\hline \multicolumn{1}{|c|}{ Tabel 1. data pengamatan siswa selama kegiatan pembelajaran berlangsung } \\
\hline & Indikator & $\begin{array}{l}\text { Siklus 1 (\%) } \\
\text { Pertemuan 1 }\end{array}$ & $\begin{array}{l}\text { Siklus 11 (\%) } \\
\text { Pertemuan 2 }\end{array}$ \\
\hline $\mathbf{1}$ & Kreativitas dalam belajar & 65 & 90 \\
\hline $\mathbf{2}$ & Mengungkapkan pendapat dengan percaya diri & 67 & 87 \\
\hline $\mathbf{3}$ & Mengerjakan tugas dengan antusias & 66 & 85 \\
\hline $\mathbf{4}$ & Menjawab pertanyaan guru dengan percaya diri & 69 & 80 \\
\hline $\mathbf{5}$ & Kooperativ & 68 & 80 \\
\hline $\mathbf{6}$ & Keantusiasan dalam belajar & 70 & 82 \\
\hline $\mathbf{7}$ & Mampu menyimpulkan hasil pembelajaran & 69 & 81 \\
\hline
\end{tabular}

Berdasarkan hasil Analisa data tentang motivasi belajar peserta didik yang telah di lakukan selama dua siklus pembelajaran ini, di peroleh hasil bahwa terjadi peningkatan motivasi belajar peserta didik kelas V11 B SMP Negeri 2 Tarakan dalam pembelajaran Ilmu Pengetahuan Sosial ( IPS ) Tema : Keadaan Penduduk Indonesia melalui penerapan Lesson Study . dataHasil pengamatan para observer peserta didik belajar dengan sungguh - sungguh dan berusaha menyelesaikan semua tugas nya serta bertanya jika tidak bisa.

Kegiatan Lesson Study dalam Meningkatkan Motivasi Belajar Peserta didik di SMP Negeri 2 Tarakan Motivasi belajar peserta didik juga diamati melalui lembar motivasi belajar peserta didk oleh observer, beberapa aspek motivasi yang diamati pada saat proses pembelajaran berlangsung. Berdsarkan analisis yang dilakukan terhadap motivasi belajar peserat didik menunjukakn bahwa secara klasikal persentase motivasi belajar peserta didik pada aspek keceriaan merupakan aspek motivasi tertinggi di kelas VII B . Peserta didik yang mempunyai motivasi dalam mengikuti pembelajaran di kelas ditandai dengan wajah yang ceria dan penuh semangat. Hal ini sesuai dengan apa yang di jelaskan Zaenab ( 2008 ) bahwa suatu pembelajaran di perlukan adanya motivasi yang terdapat pada diri peserta didik yang wajah ya 
tidak cemberut dan sering terseyum disaat pembelajaran berlangsung . Dengan demikain diperlukan kreativitas guru dalam menentukan metode yang sesuai untuk meningkatkan motivasi peserta didik terhadap pembelajaran IPS

Berdasarkan catatan peserta motivasi belajar peserta didik secara klasikal motivasi belajar peserta didik pada aspek kreatifitas dan keantusiasan di kelas VII B mengalami peningkatan . Hal ini disebabkan proses pembelajaran karena dilaksankan diruangan kelas , sehingga kondisi ruang kelas menjadi lebih kondusif. Kondisi ini tentu mejadi perhatian bagi tercapainya tujuan pembelajaran apabila guru dapat menciptakan kondisi belajar yang menyenangkan sera menggairahkan bagi peserta didik. Sehingga pelaksanaan Lesson Study di kelas berjalan sesuai dengan yang di harapkan oleh guru dan meyebabkan motivsi belajar peserta didik pada aspek keaktifan dan keantusiasan menjadi sangat tinggi

Peninggkatan motivasi belajar oleh peserta didik di kelas VII B di pengaruhi oleh metode pembelajaran yang digunakan / dipakai oleh guru . Pelaksanaan Lesson Study tersebud juga menggunakan model Discovery Learning dalam proses pembelajaran,sehingga dapat meningkatkan pemahaman bagi peserta didik dengan cara kemampuan masing - masing. Tujuan dari kerja kelompok adalah agar peserta didik dapat berfikir dan dapat memahami secara endalam materi ajar melalui media dialog dengan teman serta kelompoknya.

\section{KESIMPULAN}

Keterlaksanaan penerapan pembelajaran berbasis Lesson Study oleh guru model di SMP Negeri 2 Tarakan mengalami peningkatan pada setiap tahapan baik tahap plan, do maupun see. Motivasi belajat IPS siswa SMP Negeri 2 Tarakan pada penerapan pembelajaran berbasis Lesson Study mengalami peningkatan di bandingkan motivasi belajar sebelum penerapan pembelajaran Lesson Study. Dari keseluruhan proses dan hasil penelitian yang di peroleh terdapat saran bagi yang berminat untuk melakukan penelitian serupa atau yang ingin melanjutkan untuk mengembanngkan penelitian ini. Saran - saran nya adalah sebagai berikut : Hendaknya dalam proses pembelajaran guru lebih menjadi kreatif dalam mendesain Rencana pelaksanaan pembelajaran yang yang lebih kreatif dan inovatif sehingga para siswa menjadi lebih bersemangat didalam pembelajaran

\section{DAFTAR PUSTAKA}

BSNP. (2006). Standar Kompetensi dan Kompetesi Dasar Tingkat SMP dan MTS Mata Pelajaran IPS , Jakarta.

Djamarah dan Syaiful Bahri. (2006). Stategi Belajar Mengajar. Jakarta : Rineka cipta.

Lampiran Menteri Pendidikan Nasional No 19 Tahun 2007 Tanggal 23 Mei 2007 Tentang Standar Pengelolaan Pendidikan Nasional oleh Satuan Pendidikan Dasar dan Menengah.

Sadiman ARIF S., R. Raharjo., Anung Hryono., Raharjito. (2011). Media Pendidikan (Pengertian, Pengembangan, dan Pemanfaatan nya). Jakarta : PT Raja Grafindo Persada.

Syamsuri , Istamar dan Ibrohim. (2008). Lesson Study [ Study Pembelajaran ] Model Pembinaan Pendidikan secara Kolaboratif dan Berkelanjutan di petik dari program SISTEMS -JICA Dikabupaten Pasuruan - Jawa timur [ 2006- 2008 ] Malang FMIPA $\mathrm{UM}$

Peraturan Pemerintah NO 19 tahun. (2009). Standar Nasional Pendidikan.

Undang - Undang No 20 tahun 2003 Sistem Pendidikan Nasional.

Zainab , Nurul. (2008). Penerapan Siklus Belajar dengan Menggunakan Peta Konsep untuk meningkatkan Motivasi dan Hasil Belajar siswa di Kelas X AL-ITTIHAD Poncokusumo Malang, Skripsi tidak diterbitkan . Malang, Universitas Negeri Malang. 